JST 8 (2) (2019)
JURNAL SENI TARI
Terakreditasi SINTA 5
http://iournal.unnes.ac.id/siu/index.php/ist

\title{
Studi Laban Tari Jogi
}

\section{Denny Eko Wibowo', Mega Lestari Silalahi ${ }^{2}$, Jayanti M.Sagala ${ }^{3}$}

Universitas Universal, Kompleks Maha Vihara Duta Maitreya, Bukit Beruntung, Sungai Panas, Batam, Kepulauan Riau 29433

\begin{tabular}{l} 
Info Artikel \\
\hline Sejarah Artikel \\
Diterima : \\
23 Juli 2019 \\
Disetujui : \\
10 November 2019 \\
Dipublikasikan : \\
27 November 2019 \\
\\
\hline Keywords: \\
Jogi dance, Laban notation, \\
Laban analysis
\end{tabular}

\section{Abstrak}

Bentuk penyajian tari umumnya dipahami sebagai hal praktis yang dilakukan secara fisikal, sehingga penyajiannya dalam bentuk tertulis tak banyak dilakukan. Bentuk pencatatan yang lazim digunakan dalam bidang tari yakni notasi Laban yang dilengkapi dengan metode analisis Laban. Notasi Laban dalam bidang tari berguna sebagai metode pendokumentasian yang universal. Tari Jogi di Batam pada mulanya disajikan hanya oleh penari perempuan, sedangkan kini perkembangannya dilakukan dengan menambahkan penari laki-laki dalam pola tari berpasangan. Gerak pokok tari Jogi terdiri dari tujuh motif gerak, yang dilakukan dalam pola lantai maju, mundur, bergerak naik dan turun dalam posisi tidak berpindah tempat. Ketujuh motif gerak dasar tersebut menjadi dasar dari tari Jogi yang berkembang di Batam hingga saat ini. Tujuan penelitian ini ialah mendokumentasikan motif gerak pokok tari Jogi dengan notasi Laban dan mengkaji kualitas geraknya melalui aspek tenaga (effort) dan wujud (shape). Metode penelitian yang digunakan ialah kualitatif, dengan cara mengumpulkan data terkait koreografi tari Jogi di Batam. Hasil dari penelitian ini dapat dimanfaatkan sebagai referensi tentang tari Jogi di Batam dalam bentuk notasi gerak dan analisis kualitas geraknya melalui studi Laban.

Abstract

Dance performances commonly understood as practice way that done by physical, so that performances in the written way not much done. System of recording that prevalent used in the dance field is Laban notation that completely with methods of Laban analysis. Laban notation in the dance field useful as universal recording system. Jogi dance in Batam at first performed by female dancers, but, nowadays in the development of choreography added male dancers in the couple dance format. The main movements of Jogi dance consist of seven dance movements, that done in the onward-backward floor design and move to up and down in the stationary movements. The seventh movements are Jogi dance basic that evolve in Batam until present. The aim of this research is recording main movements of the Jogi dance with Laban notation and reviewing the quality of movements through effort and shape aspects. The research method that used by qualitative to collect any information about choreography of Jogi dance in Batam. The results of this research can used to be a references about Jogi dance in Batam in the notation of movement and analysis of movement quality by Laban studies.
\end{abstract}

(C) 2019 Universitas Negeri Semarang

\begin{tabular}{ll}
\hline Alamat korespondensi: & ISSN 2503-2585 \\
Universitas Universal, Kompleks Maha Vihara Duta Maitreya, Bukit & \\
Beruntung, Sungai Panas, Batam, Kepulauan Riau 29433 & \\
Email : 1. dennv.wibowo84@.gmail.com & mevanari@vahoo.co.id \\
2. & jaysagala68@gmail.com \\
\hline
\end{tabular}




\section{PENDAHULUAN}

Tari Jogi bagi sebagian besar masyarakat di Batam dikenal sebagai tarian khas Batam. Hal ini tak lain karena peranan penting seniman tradisional (alm) Basri sekeluarga yang berasal dari pulau Panjang. Kepopuleran tari Jogi Batam hingga kini belum diimbangi dengan kajian dan informasi ilmiah yang mudah diakses oleh masyarakat luas, sehingga keberadaannya hanya diketahui melalui informasi sekilas yang ditemukan di internet, buku, maupun media sosial. Hal ini yang melatarbelakangi penelitian tentang tari Jogi Batam ini dilakukan. Istilah Jogi sebagai tari bahkan ditemukan di Pinang Malaysia, yang disebut dengan joghee/ joghe/ joghi. Hal tersebut tentu merupakan salah satu bentuk perkembangan kebudayaan yang dipengaruhi oleh persebaran suku-suku bangsa dan telah terjadi pada waktu lampau dalam tempo yang cukup lama. Persebaran suku bangsa di dunia yang membawa serta corak kebudayaan dan perilaku hidup mereka dapat dikategorikan sebagai bagian dari proses difusi. Difusi merupakan salah satu mekanisme dinamika kebudayaan yang melibatkan perpindahan penduduk suatu wilayah tertentu beserta unsur-unsur umum kebudayaannya, bahkan peristiwa semacam ini telah terjadi sejak zaman purba dan berantai (stimulus diffusion) (Kodiran, 2000: 59). Proses ini kemudian dapat mempengaruhi produk seni pertunjukan yang memiliki persamaan sekaligus perbedaan didalamnya. Kondisi ini menjadi ihwal selama masing-masing entitas seni pertunjukan tersebut sarat dengan representasi nilai kearifan lokal dan pola budaya masyarakatnya yang khas.

Tari Jogi di Batam dulu dikenal sebagai tari sosial (social dance) yang dilakukan oleh sekelompok seniman yang singgah dari satu tempat ke tempat lain dan termasuk dalam pertunjukan Joged Dangkong. Tari Jogi pertama kali dipublikasikan ke hadapan masyarakat luas yakni ketika pengiriman misi budaya ke Pekanbaru pada dekade tahun 1900an, saat Kepulauan Riau masih bergabung menjadi bagian wilayah administratif dari provinsi Riau. Bentuk penyajian tari Jogi pada acara tersebut telah mengalami perkembangan pada aspek penyajiannya. Tari Jogi pada masa awal kemunculannya hanya dibawakan oleh penari perempuan saja, sehingga masa lalu semua penari perempuan juga bisa disebut sebagai putri joged (wawancara dengan Muhammad Zein, pada tanggal 4 Juli 2019).

Secara keseluruhan, tari Jogi yang ditampilkan dalam misi budaya ke luar Batam, tidak mengubah gerak dasar dari penari perempuan, melainkan menambahkan gerak penari laki-laki yakni seperti gerakan mendayung dan mendorong sampan (wawancara dengan Syarifah Fauziah, pada tanggal 4 Juli 2019). Perkembangan koreografi yang dilakukan dengan menambahkan karakter laki-laki dalam tari Jogi menyebabkan bentuk koreografinya menjadi komposisi duet berpasangan.

Tari Jogi yang ditampilkan dengan dua karakter yakni perempuan dan laki-laki tersebut dilakukan pada masa pemerintahan walikota Raja Usman Draman dan didukung oleh Wasnuri sebagai Kepala Dinas Pekerjaan Umum, dan Yuz Zamri sebagai Kepala Dinas Pendidikan Kota Batam. Masa perkembangan tari Jogi Batam tersebut berkenaan dengan misi budaya ke Pekanbaru yang juga diselenggarakan dengan pelatihan selama satu minggu (wawancara dengan Syarifah Fauziah, pada tanggal 4 Juli 2019). Namun demikian, pada dasarnya tari Jogi mulanya hanya ditarikan oleh karakter penari perempuan saja, yang dahulu sering dilakukan oleh Normah dengan diiringi alunan permainan biola dari (alm) Basri bersama kelompok sanggarnya dari pulau Panjang. Gerak tari Jogi terdiri dari tujuh rangkap gerak antara lain terdiri dari jalan sembah, bercermin, berbedak, berbaju, tarik dan gulung benang (wawancara dengan Normah, pada tanggal 23 Juli 2019).

Sehubungan dengan hal tersebut ruang lingkup penelitian ini adalah studi Laban terhadap tujuh motif gerak pokok dari karakter perempuan. Hal ini dilakukan karena gerak pokok inilah yang tetap dipertahankan keberadaannya, meskipun dikembangkan dengan menambahkan karakter penari laki-laki 
dalam penyajiannya. Ketujuh gerak pokok karakter penari perempuan dalam tari berpasangan yang dikembangkan pada dekade tahun 1900an antara lain disebut dengan nama duduk bertimpuh, main bakul, berbedak, bercermin, berbaju dan bergaya, berkumpul, dan bermain layanglayang (Said Kasim Al Qudhsi, 2000). Ketujuh gerak pokok tersebut juga didominasi oleh gerakan pinggul dan kaki semacam orang pincang, di mana gerakan bahu merupakan efek dari gerakan bagian tubuh tersebut (wawancara dengan Muhammad Zein, pada tanggal 4 Juli 2019).

Tujuan dari penelitian ini yakni mewujudkan informasi ilmiah terkait tari Jogi Batam yang dilakukan melalui studi Laban ditinjau dari notasi dan analisis kualitas gerak tarinya. Kedua studi terkait notasi dan analisis effort-shape dari Laban ini merupakan pengetahuan yang dikemukakan oleh Rudolf Laban yang mengulik bidang tari selama masa Perang Dunia I dan usai Perang Dunia II di Eropa (Lynn Renee Cohen, 1978:53)

\section{METODE}

Penelitian ini menggunakan metode kualitatif dengan mengumpulkan data dan informasi melalui narasumber dan informan. Studi pustaka baik yang diperoleh melalui sumber-sumber tertulis dan elektronik, juga dokumentasi audio visual yang ditemukan pada media sosial dalam rangka mendukung analisa bentuk tarinya, yang akan dikaji dengan pendekatan analisis Laban mencakup notasi dan analisis kualitas geraknya. Pendekatan Laban melalui pencatatan notasi geraknya bermanfaat dalam menyediakan detail cara menggerakkan bagian-bagian tubuh, sedangkan studi Laban dalam analisis kualitas geraknya meninjau aspek tenaga (effort) dan wujud (shape).
HASIL DAN PEMBAHASAN

Tari Jogi Batam dalam Studi Notasi Laban

Laban menyediakan metode pencatatan gerak tari yang komprehensif karena menuliskan bagian-bagian tubuh yang bergerak dan digerakkan. Hal tersebut diwujudkan dalam bentuk notasi yang bersifat universal, artinya notasi gerak tersebut dapat dimengerti dan dibaca oleh siapa saja yang memahami semacam rumus pembacaan dari notasi Laban. Jogi merupakan tarian yang dilakukan dengan menitikberatkan pada pergerakan kaki semacam jalan pincang, dengan gerakan pinggul dan sedikit gerak bahu sebagai dampak dari pergerakan keduanya.

Tari Jogi merupakan salah satu tari jenis tandak yang termasuk dalam khazanah tari khas Melayu. Sheppard menjelaskan konsep tari Melayu yang direpresentasikan melalui empat terminologi yang berarti 'memiliki nuansa' yaitu tandak, igal, liok, dan tari. Perbedaan tersebut ditentukan oleh faktor penekanan dan teknik gerak yang dilakukan melalui anggota tubuh penari. Tandak merupakan jenis tarian yang banyak dilakukan dengan gerak-gerak kaki. Penjelasan lain oleh Tengku Lah Husni yang secara taksonomis menyoroti tari Melayu Pesisir Timur Sumatera Utara dan membedakannya ke dalam tiga kelompok gerak yakni tari, tandak, dan lenggang. Pengertian tandak yang diberikan oleh Sheppard dan Tengku Lah Husni ditemukan persamaan yakni, bergeraknya bagian tubuh yang meliputi wajah,leher, jari tangan, dan kaki (Muhammad Takari, 2014:34).

Tari Jogi dilakukan berulangulang dalam irama musik yang terdiri atas kendang dan biola. Pengulangan gerak tersebut disesuaikan dengan waktu pertunjukan, karena tari senantiasa mengikuti permainan musik Jogi (wawancara dengan Syarifah Fauziah, pada tanggal 4 Juli 2019). Tari Jogi Batam yang ditarikan oleh penari perempuan terdiri dari tujuh rangkap gerak antara lain jalan sembah, jalan kacak pinggang 
(bergaya), jalan jumput bahu (berbaju), berbedak, menggesekkan kedua tangan, berkaca (pegang pipi), dan bermain layanglayang/ tarik benang gulung benang. Ketujuh rangkap gerak tersebut dapat dicatat dalam notasi Laban dengan terlebih dahulu memahami prasimbol sebagai penjelasan dari bagian-bagian tubuh.

Perbedaan antara gerak pokok penari perempuan sebelum disusun dalam koreografi duet berpasangan dengan gerak pokok yang sudah dikembangkan nampak pada urutan dan beberapa sebutan gerak yang ada. Sehubungan dengan hal tersebut dalam studi ini, sebutan ketujuh rangkap gerak tersebut akan disajikan dalam sebutan angka dan deskripsi pelaksanaan gerak tersebut. Tari Jogi menitikberatkan pada gerakan bagian tubuh yang meliputi tangan (telapak), kaki, badan, dan kepala. Bagian tubuh yang lain seperti bahu dan pinggul menyesuaikan dengan gerakan utama yang dilakukan (lihat gambar 1).

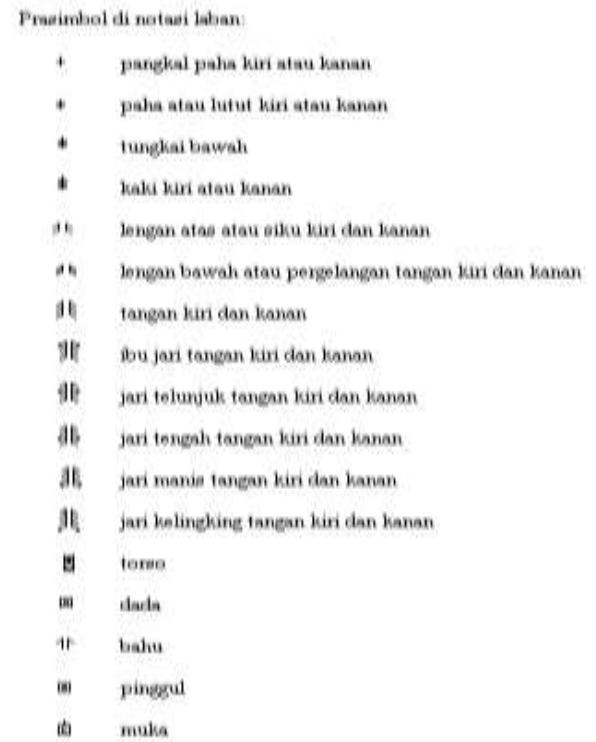

Notasi Laban dilengkapi dengan kunci arah dari posisi jari tangan yang secara garis besar terdiri dari sikap sembah, mengepal, menjimpit bahu, menunjuk, dan membuka. Setiap motif gerak dilakukan dengan pola lantai yang sama yakni maju-mundur, turun, duduk simpuh hadap kiri-kanan, naik, dan jalan mundur. Setiap gerakan dalam notasi Laban yang disajikan ini digambrakan dalam hitungan 1 x 8, dimana masingmasing gerak terdiri dari 6 bar notasi atau $8 \times 8$ hitungan. Akan tetapi gerakan tari Jogi yang dilakukan pada dasarnya mengikuti alunan musik pengiring sehingga kondisi tersebut menentukan kapan setiap motif gerak akan dilakukan dan dihentikan/ berganti (lihat gambar 2).

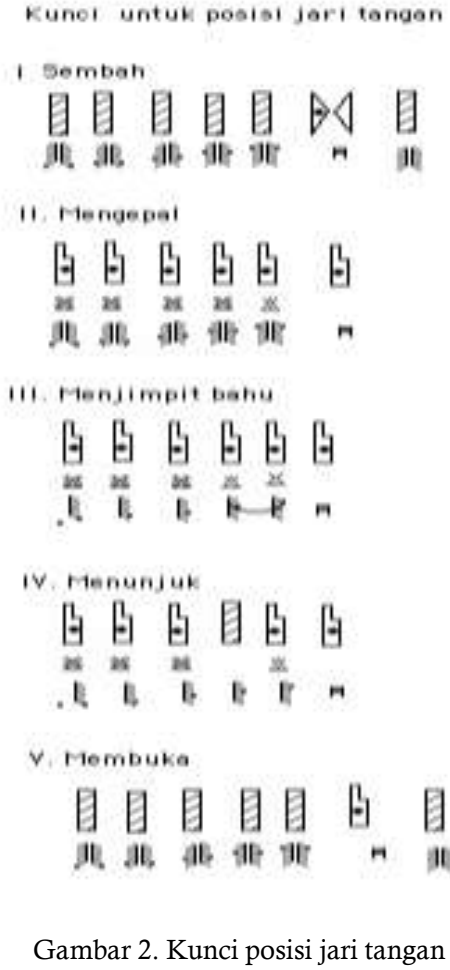

Notasi Laban juga dilengkapi dengan kunci arah hadap yang meliputi posisi arah di tempat, ke belakang, ke depan, ke samping kanan/ kiri, dan diagonal ke segala arah. Perbedaan level yang berkenaan dengan posisi tubuh penari atau posisi bagian tubuh penari yang berada dalam posisi tinggi, sedangm dan rendah juga ditunjukkan dengan perbedaan penulisan notasi yang meliputi tiga macam (lihat gambar 3 ). 

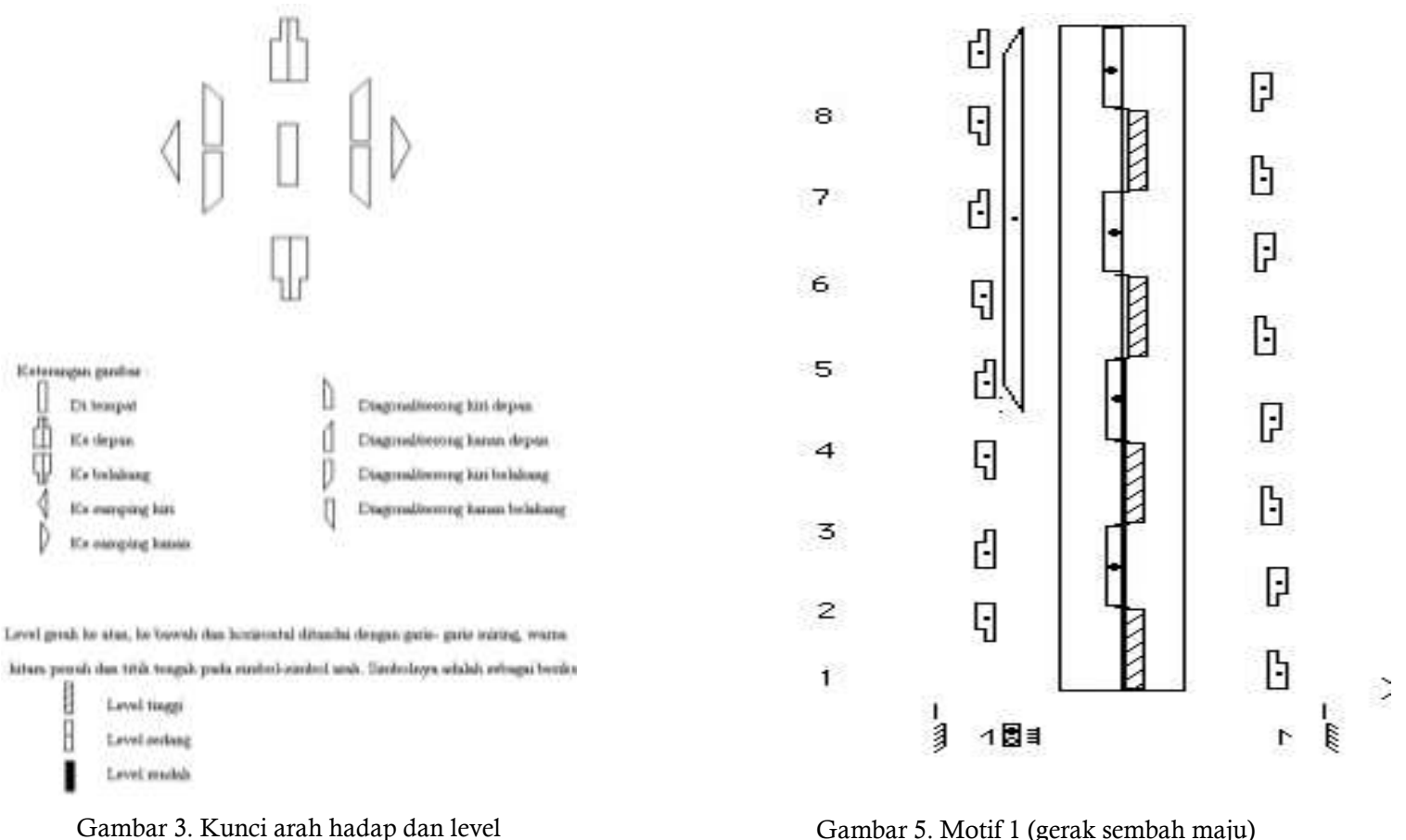

\section{Motif 1 (Jalan Lenggang dan gerak Sembah)}

Gerakan ini diawali dengan jalan lenggang di tempat (lihat gambar 4), kemudian dilakukan jalan maju dengan posisi telapak tangan sembah di depan dada (lihat gambar 5). Gerakan kaki berjingkat, pinggul dan bahu mengikuti gerakan kaki. Gerakan ini dilakukan dalam pola lantai maju-mundur (lihat gambar 6 dan 7), posisi turun duduk simpuh dan naik kembali (lihat gambar 8 dan 9), naik, dan jalan mundur berlenggang (lihat gambar 10).

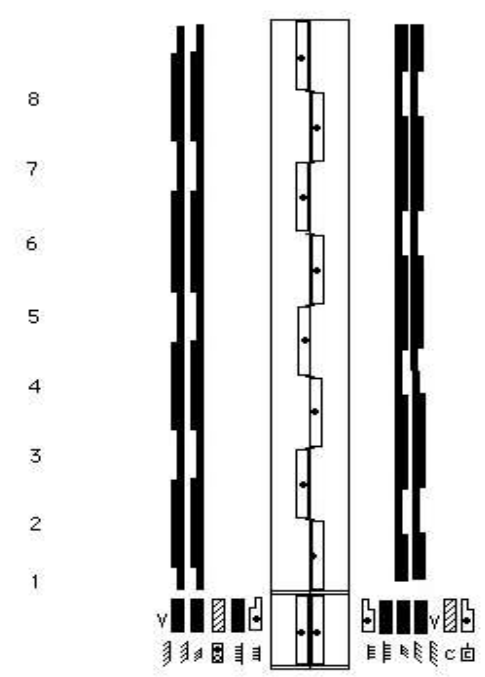




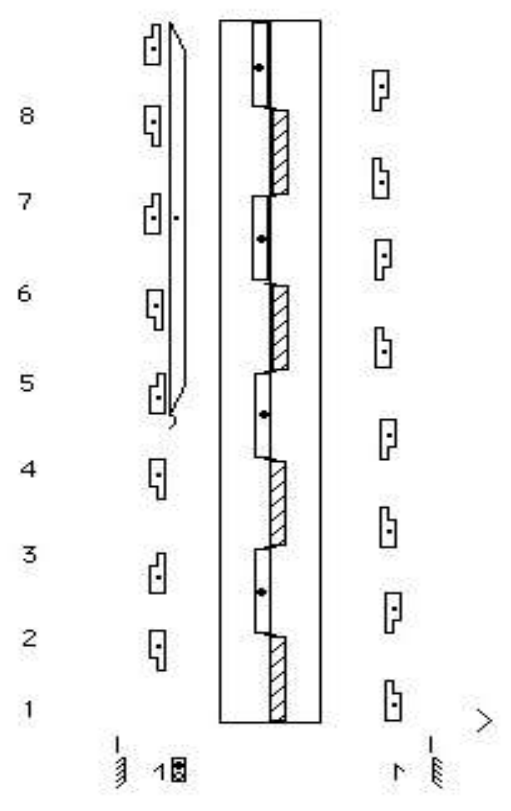

Gambar 7. Motif 1 (gerak sembah hadap kiri)

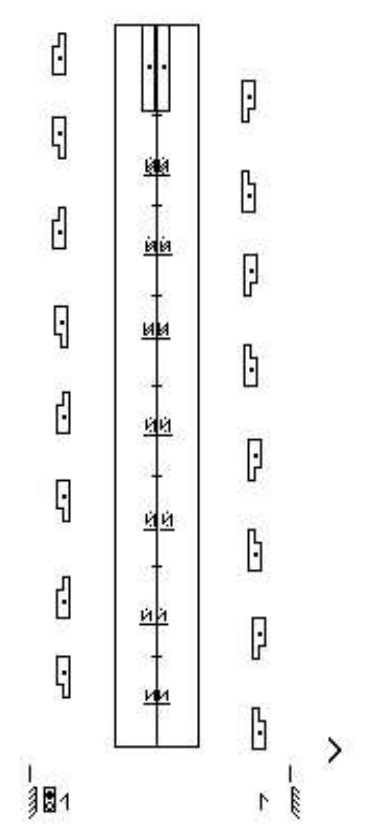

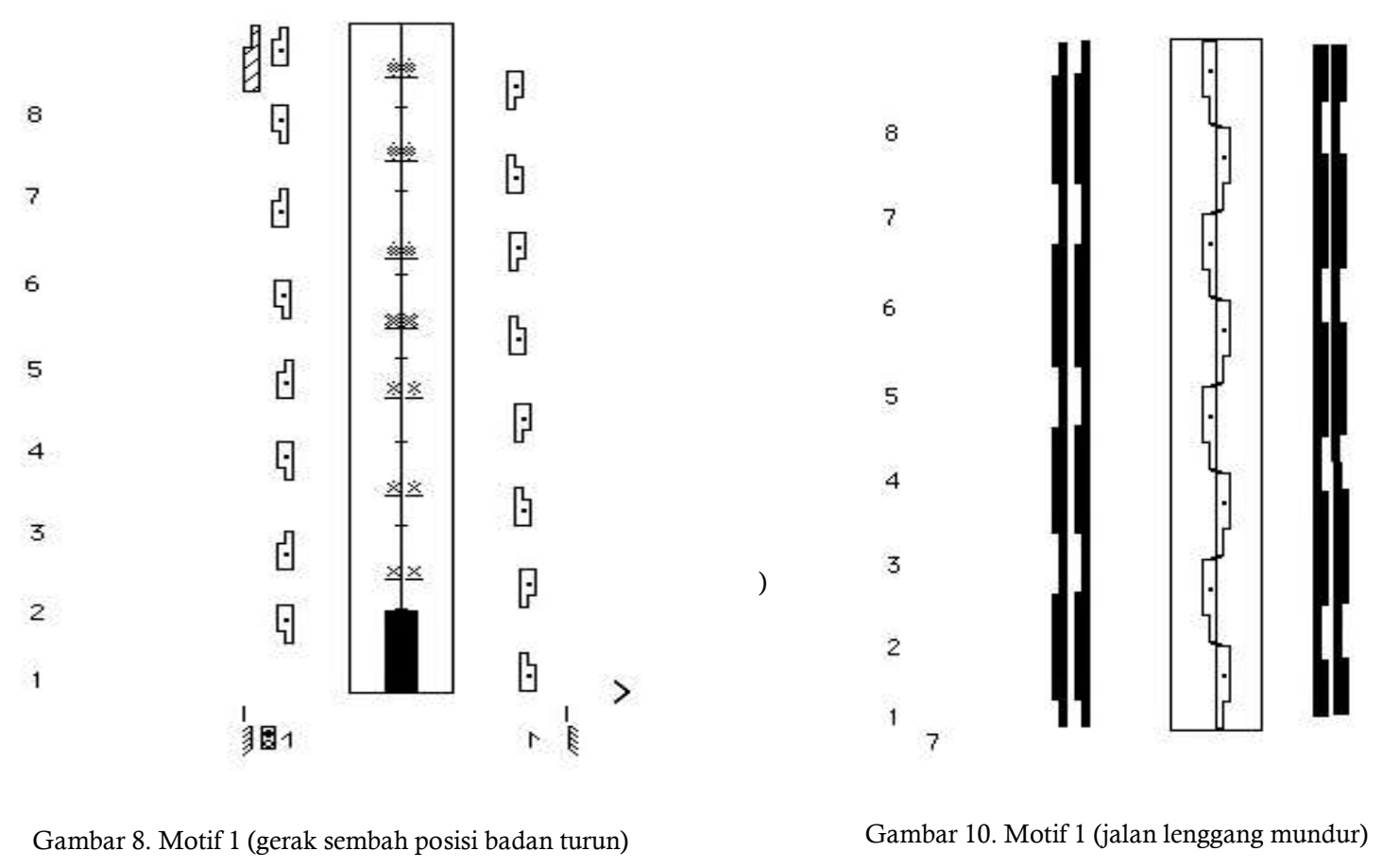




\section{Motif 2 (gerak Bergaya - kacak pinggang)}

Gerakan ini dilakukan dalam gerak kaki berjingkat dan kedua tangan ditekuk di samping pinggang. Gerakan dilakukan dengan jalan maju, hadap kiri, hadap kanan, posisi badan turun-naik, dan mundur dengan jalan lenggang.

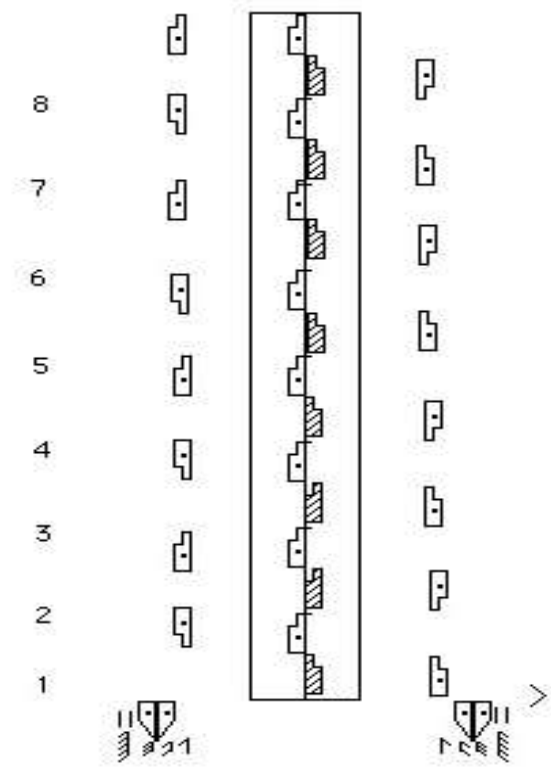

Gambar 11. Motif 2 (gerak Bergaya - kacak pinggang)

\section{Motif 3 (gerak Berbaju - Jumput Bahu)}

Gerakan ini dilakukan dalam gerak kaki berjingkat, tangan kanan berada di atas bahu kanan dengan posisi menjumput. Tangan kiri berada di pinggang sebelah kiri dengan posisi kacak pinggang.

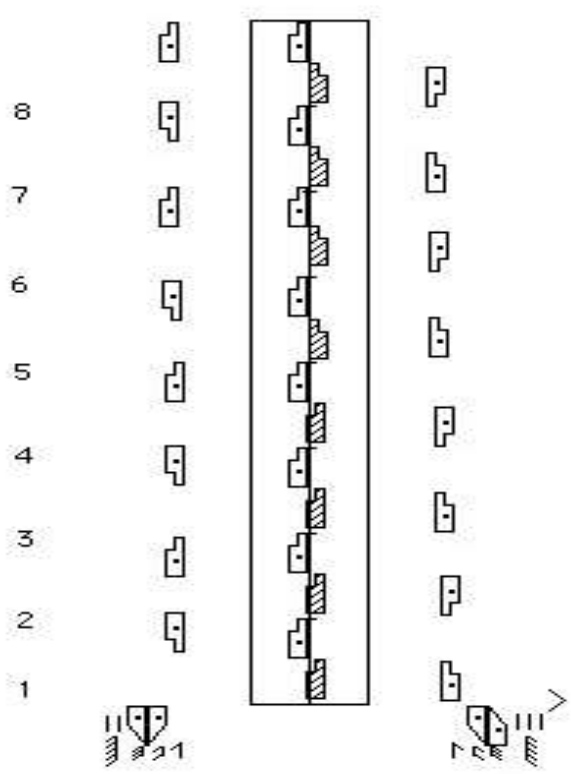

Gambar 12. Motif 3 (gerak Berbaju - Jumput Bahu)

Motif 4 (gerak menggesekan kedua tangan)

Gerakan ini dilakukan dengan menggesekkan kedua tangan dalam posisi lurus di depan tubuh. Tangan kanan berada di atas tangan kiri.

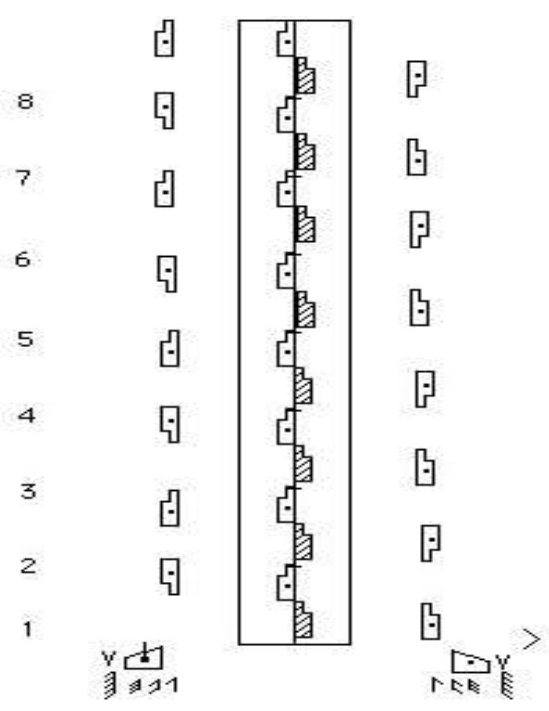

Gambar 13. Motif 4 (gerak menggesekkan kedua tangan) 


\section{Motif 5 (gerak Berbedak)}

Gerakan ini dilakukan dengan membuka telapak tangan kiri di depan wajah, dan telapak tangan kanan berada di dekat telapak tangan kiri dengan sedikit pergerakan seperti memutar searah jarum jam.

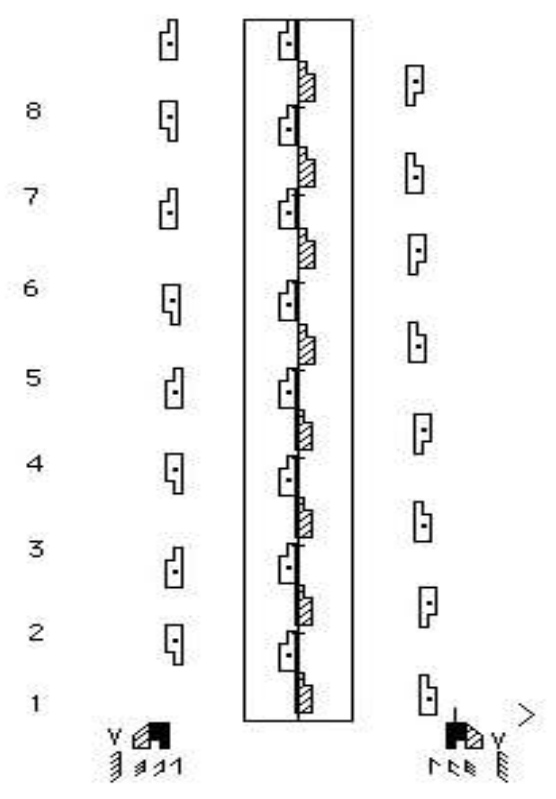

Gambar 14. Motif 5 (gerak Berbedak)

\section{Motif 6 (gerak Berkaca)}

Gerakan ini dilakukan dengan posisi tangan kanan di tekuk dan jari telunjuk kanan ditaruh di pipi kanan. Tangan kiri posisi ditekuk melintang di depan tubuh dan ujung telapak tangan kiri menopang siku tangan kanan.

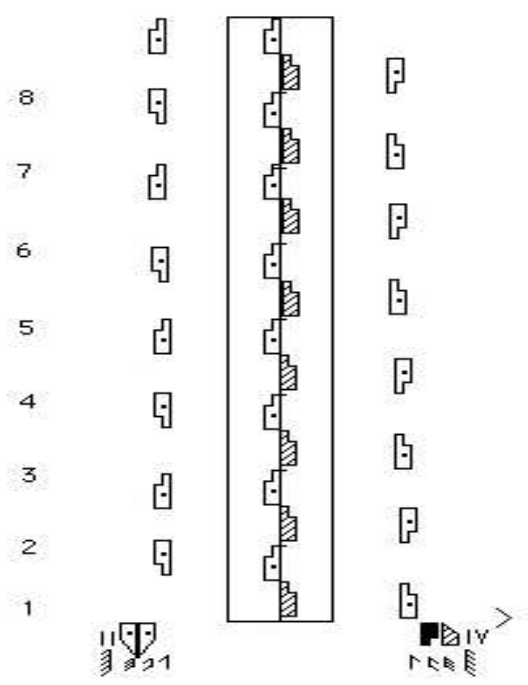

Gambar 15. Motif 6 (gerak berkaca - menunjuk pipi kanan)

Motif 7 (gerak tarik benang-gulung benang/ bermain layang-layang)

Gerakan ini kombinasi antara dua gerakan yakni merentangkan kedua tangan dari depan badan ke arah samping badan, disusul dengan menggulung kedua tangan di depan badan.

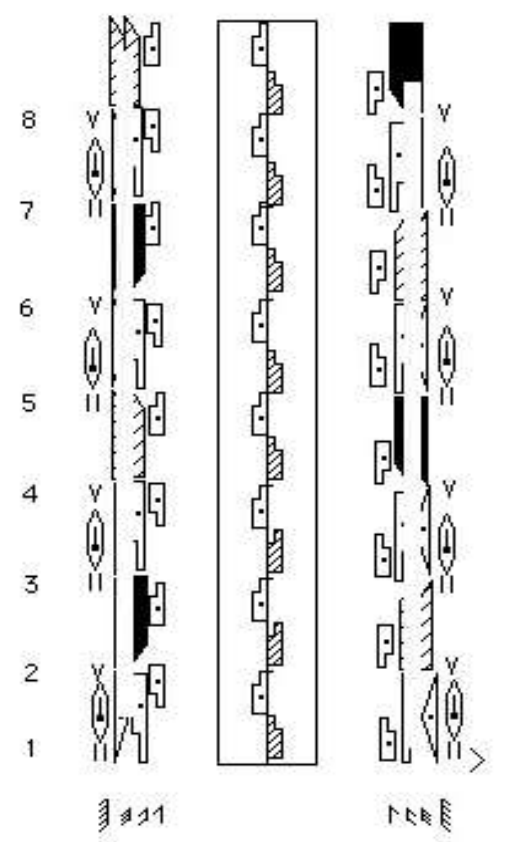

Gambar 16. Motif 7 (gerak tarik benang-gulung benang/ bermain layang-layang) 
Tujuh rangkap gerak tersebut di atas merupakan gerakan pokok penari perempuan dalam tari Jogi sebelum mengalami perkembangandan perubahan dalam susunan komposisi duet berpasangan. Perkembangan selanjutnya yang dilakukan terkait pada variasi gerak dan pola lantai, yang dipegaruhi keberadaan karakter penari laki-laki dalam komposisi duet berpasangan. Perkembangan dan perubahan komposisi tari tersebut dilakukan saat tari Jogi dipersembahkan dalam kegiatan misi budaya ke luar Batam, yang disusun oleh Tim Penata Tari yaitu Said Kasim Al Qudhsi, Makmur Muhammad, Syarifah Fauziah, Raja Rumeli Diska, Kamaliah, Iskandar, dan Muhammad Zen (Said Kasim Al Qudhsi, 2019).

Tari Jogi Batam dalam Studi Analisis Laban

Tari Jogi Batam secara umum terlihat monoton dan berulang-ulang. Hal tersebut terjadi karena bagian tubuh utama yang digerakkan yakni kaki berjingkat dan pinggul, sedangkan gerakan bahu merupakan efek dari gerak kedua bagian tubuh tersebut. Kualitas gerak yang dari pinggul, kaki, dan bahu akan dibedah dengan analisis Laban terkait aspek tenaga (effort) dan wujud (shape).

Aspek tenaga (effort) terdiri dari empat hal yakni aliran tenaga (bebas dan terikat); ruang (tak langsung dan langsung), berat (ringan dan kuat), dan waktu (terus-menerus dan tiba-tiba). Kualitas gerak tari juga ditinjau dari aspek perwujudannya yang meliputi aliran wujud (membuka-menutup), garis arah (maju-mundur), dan perwujudannya sendiri. Analisis aspek tenaga (effort) digambarkan dalam bentuk notasi/ diagram sebagai berikut:

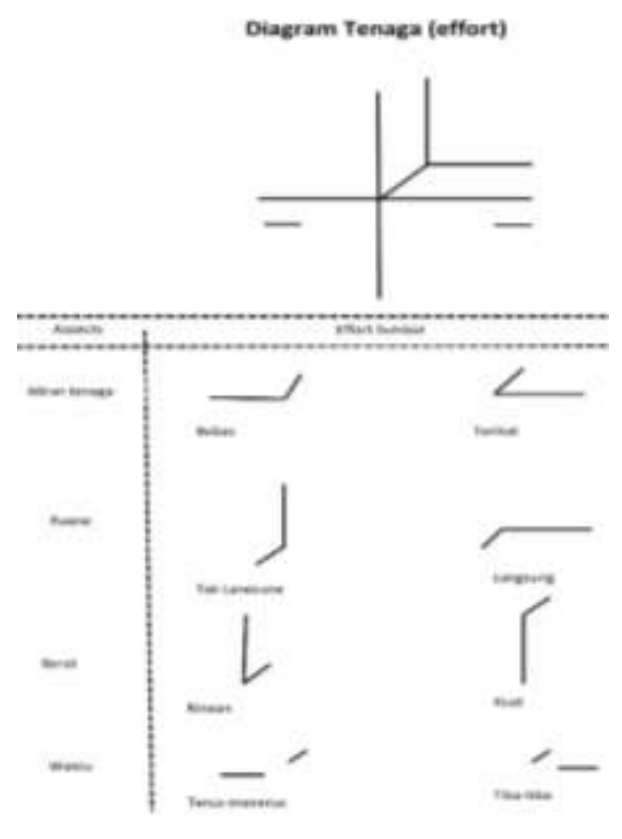

Gambar 17. Diagram Tenaga (effort)

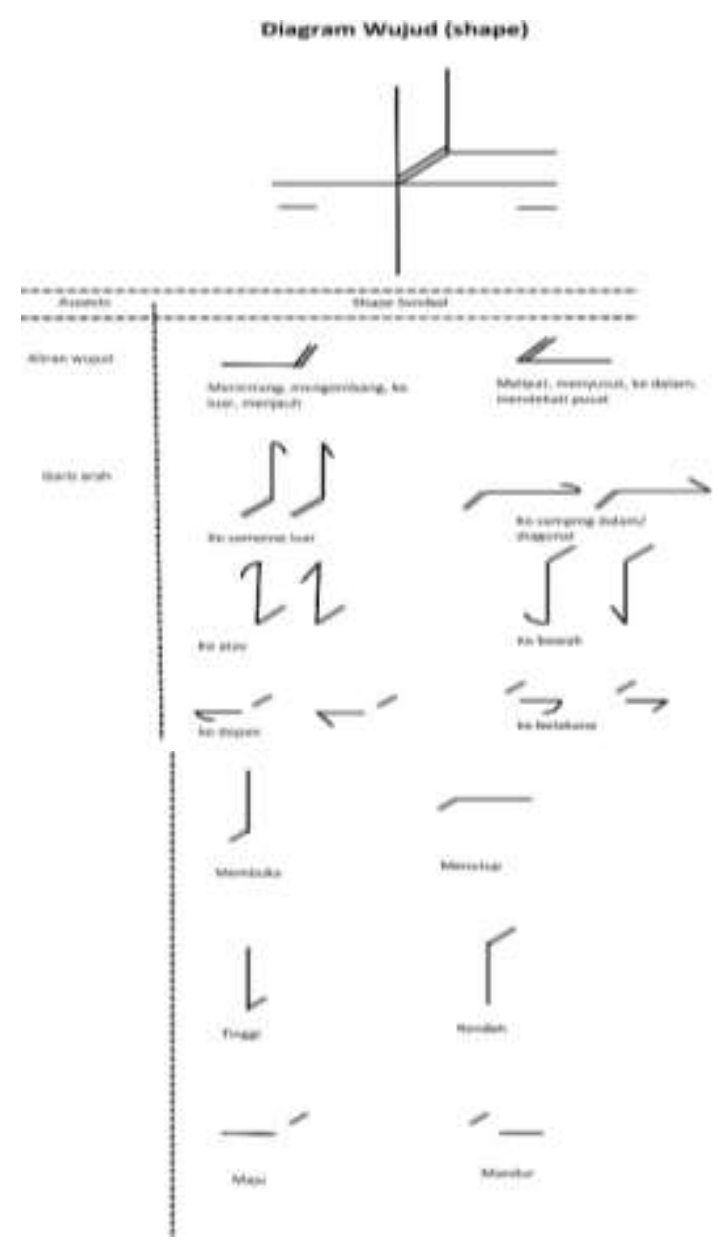

Gambar 18. Diagram Wujud (shape) 
Tari Jogi Batam identik dengan gerakan kaki seperti orang pincang diikuti gerak pangkal paha kanan dan bahu kanan yang dinamis. Pergerakan yang wajar tidak memerlukan tenaga kuat dalam menggoyangkan bagian tubuh seperti bahu dan pinggul. Perkembangan tari Jogi kini tak hanya mengalami variasi pada komposisi tarinya, melainkan juga kualitas pergerakan dari penari yang membawakannya.

Tari Jogi Batam berpusat pada pergerakan kaki seperti jalan pincang, itu berarti terjadi pergerakan kuat seperti menginjak dengan posisi kaki kanan jinjit dan mengangkatnya kembali. Pergerakan kaki kanan ini selalu dilakukan saat menari dengan sifat tenaga kuatlangsung-tiba-tiba. Aspek wujudnya dapat dicermati dengan sifanya menjauhke bawah-rendah.

Tenaga : kuat-langsung-tiba-tiba " ringanlangsung-tiba-tiba (menginjak/menekan) dilanjutkan gerak mengapung)

Wujud : membuka - ke bawah - rendah

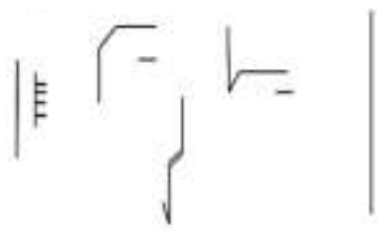

Gambar 19. Simbol aspek tenaga effort dan wujud (shape) gerakan kaki.

Pergerakan pinggul atau lebih spesifik di bagian pangkal paha kanan, dikategorikan mengikuti pergerakan kaki kanan, yang memiliki sifat tenaga ringanlangsung-tiba-tiba. Gerakan bagian tubuh lain seperti bahu juga mengikuti pergerakan kaki, sehingga memiliki kualitas yang sama dengan gerak pangkal paha kanan. Aspek wujudnya digambarkan dengan kualitas membukamerentang/ menjauh-ke depan dan menutup-mendekati pusat tubuh-ke belakang.
Tenaga : ringan- langsung- tiba-tiba

Wujud : membuka - merentang - ke depan » menutup-mendekati pusat tubuh- ke belakang

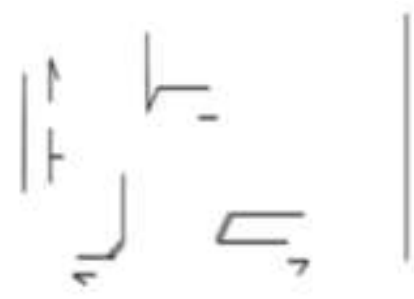

Gambar 20. Simbol aspek tenaga effort dan aspek wujud (shape) untuk gerak bahu kanan dan pangkal paha kanan.

\section{SIMPULAN}

Tari Jogi Batam yang dahulu disajikan oleh Normah bersama kelompok seniman Warisan Pantai Basri dari Pulau Panjang memuat tujuh rangkap gerak pokok. Gerak tersebut dibawakan oleh karakter perempuan. Perkembangan yang dilakukan pada komposisi tarinya meliputi penambahan karakter laki-laki dalam bentuk duet berpasangan, pengembangan gerak tari berdasarkan tujuh gerak pokok yang telah ada, serta iringan musik yang terstruktur dalam irama hitungan yang jelas.

Fungsi penelitian yang mewujudkan tari Jogi Batam dalam notasi Laban dan analisis kualitas geraknya ini merupakan upaya pencatatan teks tari yang dapat dipahami secara universal. Sebagian besar teknologi dokumentasi termasuk audio visual tidak sepenuhnya menjelaskan keterangan gerak tari yang mencakup detail dan kualitasnya, sehingga keberadaan notasi Laban dan analisis aspek tenaga (effort) dan wujud (shape) sangat diperlukan.

Tujuh gerak yang dipaparkan dalam notasi Laban menyangkut rincian bagian-bagian tubuh yang digerakkan, sedangkan kualitas pergerakan kaki, pangkal paha, dan bahu dapat dicermati pada analisis aspek tenaga (effort) dan wujud (shape), sehingga ketidaktepatan pergerakan beberapa motif yang ada pada teks tari Jogi Batam dapat dihindari. 
Sebagian besar seni pertunjukan di Batam, dan Kepulauan Riau pada umumnya diwariskan dan diajarkan secara lisan dari satu generasi ke generasi selanjutnya, sehingga perwujudan bentuk pencatatan teksnya, dalam hal ini gerak untuk bidang seni tari sangat diperlukan. Sehubungan dengan hal tersebut, produktivitas penelitian serupa yang tahap awal mendokumentasikan tari melalui studi Laban hendaknya senantiasa dilakukan sebagai bagian dari penelitian yang menggunakan pendekatan etnokoreologi, disamping pendokumentasian tari dalam bentuk audio visual.

\section{UCAPAN TERIMAKASIH}

Terimakasih tak terhingga disampaikan kepada narasumber dan informan yang turut membantu memberikan informasi terkait tari Jogi Batam dan studi Laban, yakni Normah, Muhammad Zen, Syarifah Fauziah, T.A. Kandiraras, dan Aziah.

\section{DAFTAR PUSTAKA}

Hutchinson, Ann. 1971. Labanotation or Kinetography Laban.

Kasim Al Qudhsi, Said., Makmur Muhammad, Syarifah Fauziah, dkk. 2000. Teori dan Ragam Tari Jogi. Batam: Dinas Pendidikan dan Kebudayaan.

Kodiran. 2000. "Perkembangan Kebudayaan dan Implikasinya terhadap Perubahan Sosial di Indonesia" dalam Jurnal Ketahanan Nasional Vol.5, No.2 (2000). Yogyakarta: Study Program of National Resilience, Graduate School, Universitas Gadjah Mada.

Renee Cohen, Lynn. 1978. "Introduction to Labananalysis: Effort/Shape" dalam Essays Dance Research: Dance Research Annual IX CORD 1978. New York: Congress in Research in Dance.

Takari, Muhammad. 2014. Ronggeng dan Serampang Dua Belas dalam Kajian Ilmu-ilmu Seni. Medan: USU Press.
Dokumentasi audio visual tari Jogi dalam Ujian Mata Kuliah Tari Etnis Melayu 1, Program Studi Seni Tari Universitas Universal Batam pada tanggal 26 Mei 2019.

Dokumentasi audio visual tari Jogi dalam video berjudul 'Belajar Tari Jogi' yang dilakukan oleh Muthiara Maharani bersama Normah, dipublikasikan pada Youtube oleh Wahyu Ikhtiar Ramadhan pada tanggal 21 Oktober 2013. https://youtu.be/8OzHOTIGRO $\underline{E d}$ 